such as one finds in the psychoanalytical theories. This looseness allows anyone to interpret the theories as he fancies, and tends to reduce them to art rather than science. Adler himself felt this, and a year ago told the writer that he thought that many who preached his views did not properly understand them. $\mathrm{He}$ was reluctant to build a rigid system, however, since he felt that the human mind was not easily crushed into any inflexible mould.

Adler worked in Vienna until a few years ago, when he left and accepted a professorship in America. $\mathrm{He}$ has visited England nearly every year since in order to lecture. $\mathrm{He}$ was a lecturer of singular patience, and would answer questions long after his lectures were supposed to have finished. $\mathrm{He}$ was a man of great friendliness-those who knew him might differ from him in theory but they could not quarrel with him in person for he never showed the aggression of which he wrote so much.

\section{Major J. H. Hardcastle}

MaJor John Herschel Hardcastle, who died at Sidcup, Kent, on April 21, was born on May 9, 1870, at Netherhall, Bury St. Edmunds, a son of the late Henry Hardcastle, barrister. His maternal grandfather was Sir John Herschel, the astronomer, and his great-grandfather was the famous discoverer of the planet Uranus.

Hardcastle was educated at Haileybury and the Royal Military Academy, Woolwich, passing out ninth from the latter ; thence he received his commission in the Royal Regiment of Artillery in 1889. $\mathrm{He}$ was promoted to captain in 1899. In 1902 he joined the advanced class for artillery officers at the Ordnance College, Woolwich, and there came under the influence of Sir George Greenhill. After obtaining the 'p.a.c.' certificate he was employed by the Ordnance Board at Woolwich in 1904-6 on important research work on the resistance of the air to artillery projectiles. This work culminated in the production of the official Ballistic Tables, in the compilation of which he assisted. These tables are still used.

Retired from the Army in 1906, Hardcastle thereafter devoted himself to research work in internal ballistics and small arms, working successively with the firms of Kynoch and Nobel's Explosives. During this period he introduced the pointed bullet. At the beginning of the Great War he returned to Woolwich, and was given charge of the small arms range in the Arsenal. Here he continued his researches into the ballistics of small arms, and towards the end of the War, produced formulæ which facilitated the rapid calculation of small arms ballistics. He remained at Woolwich until 1924 and assisted in the compilation of the "Text Book of Small Arms". After his retirement from the Service he acted as ballistic consultant to Imperial Chemical Industries, Ltd., and B.S.A. Guns, Ltd.

Most of Hardcastle's publications are in the form of papers and articles in the Royal Artillery Journal. $\mathrm{He}$ put his scientific knowledge of small arms to practical use, as he was a very fine rifle shot and was in the English Elcho team.

\section{Prof. W. Natanson}

PoLrsh science has sustained a heavy loss by the death, on February 26, of Prof. Wtadyslaw Natanson, who had occupied the chair of physics at the Jagellonian University of Cracow since 1904, after having been assistant professor there since 1894 .

Natanson was born in Warsaw on June 18, 1864, his uncle, Jacob Natanson, being a Polish chemist of some distinction. He graduated as doctor of philosophy at Dorpat in 1888, having previously studied at St. Petersburg, Graz and Cambridge. He then went to Cracow, where his post-graduate researches in physics gained him the doctorate of that university too (1891). Three years later he became Docent and continued his work at Cracow until his death.

Practically all his life, Natanson was working in adverse circumstances. It was never easy for him to secure adequate equipment for his laboratory from the Austrian authorities in pre-War days, nor had the Polish Government funds to spare for several years after the country had regained its independence. In spite of this, Natanson succeeded in making valuable contributions to his science, particularly by his publications on the kinetic theory of gases, which he developed to explain phenomena connected with diffusion, expansion by heat, vortex rings, molecular collisions, etc.

Theoretical and mathematical papers from his pen and dealing with isothermal formulæ, Clerk Maxwell's law, the kinetic theory and dissociation phenomena have appeared from time to time in British periodicals, but most of his work was published in Continental journals. In 1903 he observed the accidental double refraction of liquids, which he endeavoured to explain by a molecular theory of refraction, reflection and extinction. $\mathrm{He}$ is perbaps best known in Great Britain for his investigations on the dissociation of nitrogen peroxide on heating, and its re-association on cooling.

For his own countrymen Natanson contributed articles on scientific phenomena (several, for example, dealt with the blue colour of the sky) to the semipopular reviews and he also wrote some standard text-books of physies. His "Elements of Physics", first published at Lwów in 1894, has gone through five editions. Prof. Natanson also had a wide knowledge of the history of science, and his biographical sketches of Bacon, Newton, Lord Kelvin and others did much to stimulate an interest in British culture and science among the Polish people. He was one of the original members of the Cracow Academy of Sciences, and was for seven years the editor of its publications. Later his work gained him recognition abroad, and among other distinctions he held the office of vice-president of the International Union of Physics.

G. D.

WE regret to announce the following deaths:

M. Louis Ravaz, correspondant for the Section of Rural Economy of the Paris Academy of Sciences.

Prof. J. M. Reade, professor of botany in the University of Georgia, on May 8, aged sixty-one years. 